4

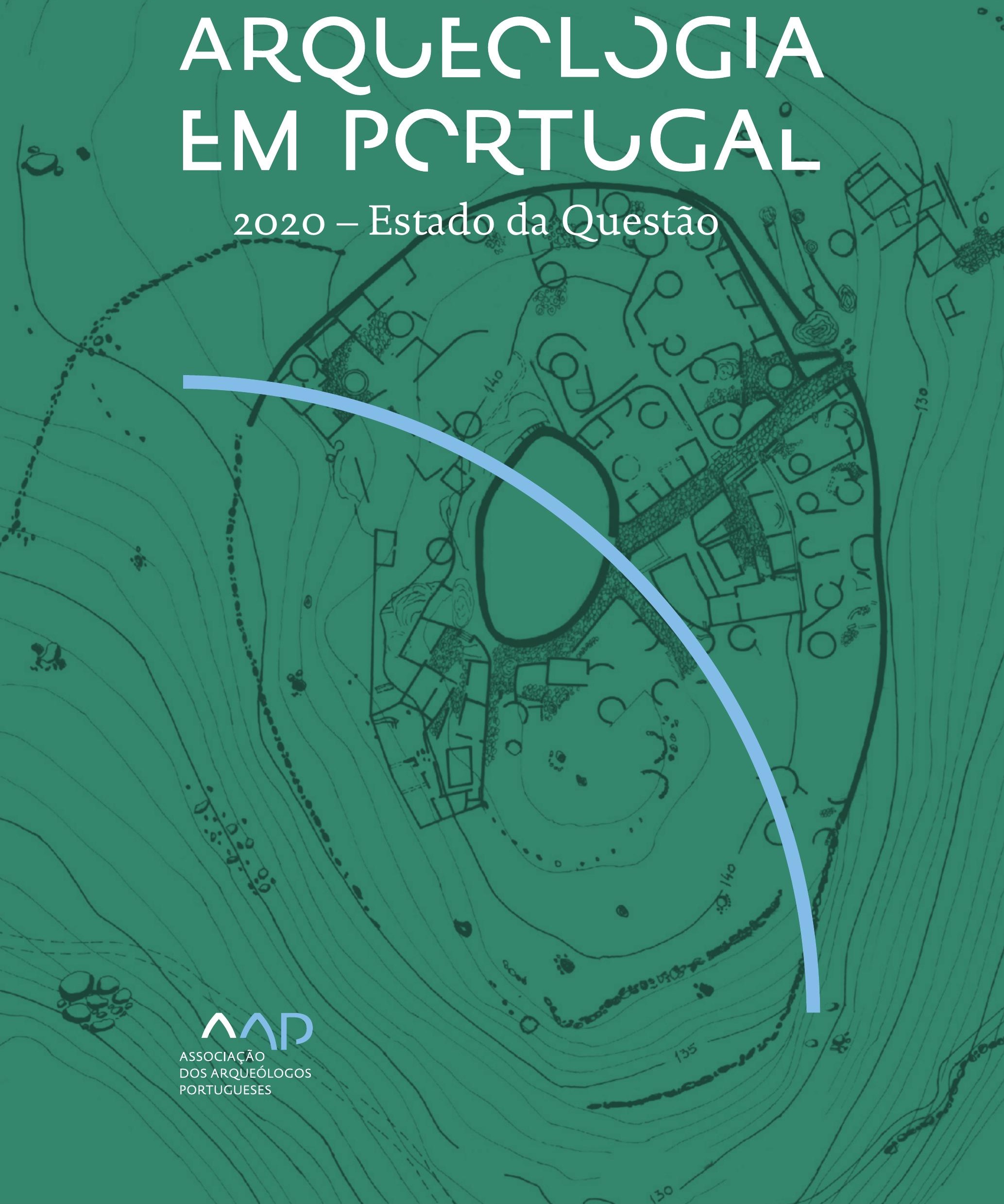


Coordenação editorial: José Morais Arnaud, César Neves e Andrea Martins Design gráfico: Flatland Design

AAP - ISBN: 978-972-9451-89-8

CITCEM - ISBN: 978-989-8970-25-1

Associação dos Arqueólogos Portugueses e CITCEM

Lisboa, 2020

O conteúdo dos artigos é da inteira responsabilidade dos autores. Sendo assim a Associação dos Arqueólogos Portugueses declina qualquer responsabilidade por eventuais equívocos ou questões de ordem ética e legal.

Desenho de capa:

Planta do castro de Monte Mozinho (Museu Municipal de Penafiel).

\section{$\hat{\wedge} \mathrm{P}$}

DOS ARQUEÓLOGOS PORTUGUESES

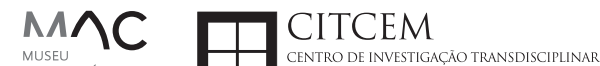
MUSEU
ARQUELLÓGICO
DO CARMO
U.PORTO

FLUP FACULDADE DE LETRAS
UNIVERSIDADE DO PORTO

Apoio

EC para a Ciência 


\section{Índice}

15 Prefácio

José Morais Arnaud

\section{Historiografia e Teoria}

17 Território, comunidade, memória e emoção: a contribuição da história da arqueologia (algumas primeiras e breves reflexões)

Ana Cristina Martins

25 Como descolonizar a arqueologia portuguesa?

Rui Gomes Coelho

41 Arqueologia e Modernidade: uma revisitação pessoal e breve de alguns aspetos da obra homónima de Julian Thomas de 2004

Vítor Oliveira Jorge

57 Dados para a História das Mulheres na Arqueologia portuguesa, dos finais do século XIX aos inícios do século XX: números, nomes e tabelas

Filipa Dimas / Mariana Diniz

73 Retractos da arqueologia portuguesa na imprensa: (in)visibilidades no feminino

Catarina Costeira / Elsa Luís

85 Arqueologia e Arqueólogos no Norte de Portugal Jacinta Bugalhão

101 Vieira Guimarães (1864-1939) e a arqueologia em Tomar: uma abordagem sobre o território e as gentes

João Amendoeira Peixoto / Ana Cristina Martins

115 Os memoráveis? A arqueologia algarvia na imprensa nacional e regional na presente centúria (2001-2019): características, visões do(s) passado(s) e a arqueologia

enquanto marca

Frederico Agosto / João Silva

129 A Evolução da Arqueologia Urbana e a Valorização Patrimonial no Barlavento Algarvio: Os casos de Portimão e Silves

Artur Mateus / Diogo Varandas / Rafael Boavida

\section{Gestão, Valorização e Salvaguarda do Património}

145 O Caderno Reivindicativo e as condições de trabalho em Arqueologia Miguel Rocha / Liliana Matias Carvalho / Regis Barbosa / Mauro Correia / Sara Simões / Jacinta Bugalhão / Sara Brito / Liliana Veríssimo Carvalho / Richard Peace / Pedro Peça / Cézer Santos

155 Os Estudos de Impacte Patrimonial como elemento para uma estratégia sustentável de minimização de impactes no âmbito de reconversões agrícolas Tiago do Pereiro

165 Salvaguarda de Património arqueológico em operações florestais: gestão e sensibilização Filipa Bragança / Gertrudes Zambujo / Sandra Lourenço / Belém Paiva / Carlos Banha / Frederico Tatá Regala / Helena Moura / Jacinta Bugalhão / João Marques / José Correia / Pedro Faria / Samuel Melro

179 Os valores do Património: uma investigação sobre os Sítios Pré-históricos de Arte Rupestre do Vale do Rio Côa e de Siega Verde José Paulo Francisco 
189 Conjugando recursos arqueológicos e naturais para potenciar as visitas ao Geoparque Litoral de Viana do Castelo (Noroeste de Portugal)

Hugo A. Sampaio / Ana M.S. Bettencourt / Susana Marinho / Ricardo Carvalhido

203 Áreas de Potencial Arqueológico na Região do Médio Tejo: Modelo Espacial Preditivo Rita Ferreira Anastácio / Ana Filipa Martins / Luiz Oosterbeek

223 Património Arqueológico e Gestão Territorial: O contributo da Arqueologia para a revisão do PDM de Avis

Ana Cristina Ribeiro

237 A coleção arqueológica do extinto Museu Municipal do Porto - Origens, Percursos e Estudos

Sónia Couto

251 Valpaços - uma nova carta arqueológica

Pedro Pereira / Maria de Fátima Casares Machado

263 Arqueologia na Cidade de Peniche

Adriano Constantino / Luís Rendeiro

273 Arqueologia Urbana: a cidade de Lagos como caso de Estudo Cátia Neto

285 Estratégias de promoção do património cultural subaquático nos Açores. O caso da ilha do Faial

José Luís Neto / José Bettencourt / Luís Borges / Pedro Parreira

297 Carta Arqueológica da Cidade Velha: Uma primeira abordagem

Jaylson Monteiro / Nireide Tavares / Sara da Veiga / Claudino Ramos / Edson Brito /

Carlos Carvalho / Francisco Moreira / Adalberto Tavares

311 Antropologia Virtual: novas metodologias para a análise morfológica e funcional Ricardo Miguel Godinho / Célia Gonçalves

\section{Didáctica da Arqueologia}

327 Como os projetos de Arqueologia podem contribuir para uma comunidade culturalmente mais consciente Alexandra Figueiredo / Claúdio Monteiro / Adolfo Silveira / Ricardo Lopes

337 Educação Patrimonial - Um cidadão esclarecido é um cidadão ativo! Ana Paula Almeida

351 A aproximação da Arqueologia à sala de aula: um caso de estudo no $3^{\circ}$ ciclo do Ensino Básico Luís Serrão Gil

363 Arqueologia 3.o - Pensar e comunicar a Arqueologia para um futuro sustentável Mónica Rolo

377 “Conversa de Arqueólogos" - Divulgar a Arqueologia em tempos de Pandemia Diogo Teixeira Dias

389 Escola Profissional de Arqueologia: desafios e oportunidades Susana Nunes / Dulcineia Pinto / Júlia Silva / Ana Mascarenhas

399 Os Museus de Arqueologia e os Jovens: a oferta educativa para o público adolescente Beatriz Correia Barata / Leonor Medeiros

411 O museu universitário como mediador entre a ciência e a sociedade: o exemplo da secção de arqueologia no Museu de História Natural e da Ciência da Universidade do Porto (MHNC-UP)

Rita Gaspar 
421 Museu de Lanifícios: Real Fábrica de Panos. Atividades no âmbito da Arqueologia Beatriz Correia Barata / Rita Salvado

427 Arqueologia Pública e o caso da localidade da Mata (Torres Novas) Cláudia Manso / Ana Rita Ferreira / Cristiana Ferreira / Vanessa Cardoso Antunes

431 Do sítio arqueológico ao museu: um percurso (também) didático Lídia Fernandes

447 Estão todos convidados para a Festa! E para dançar também... O projecto do Serviço Educativo do Museu Arqueológico do Carmo na $5^{\underline{a}}$ Edição da Festa da Arqueologia Rita Pires dos Santos

459 O “Clã de Carenque”, um projeto didático de arqueologia Eduardo Gonzalez Rocha

469 Mediação cultural: peixe que puxa carroça nas Ruínas Romanas de Troia Inês Vaz Pinto / Ana Patrícia Magalhães / Patrícia Brum / Filipa Santos

481 Didática Arqueológica, experiências do Projeto Mértola Vila Museu Maria de Fátima Palma / Clara Rodrigues / Susana Gómez / Lígia Rafael

\section{Arte Rupestre}

497 Os inventários de arte rupestre em Portugal Mila Simões de Abreu

513 O projeto FIRST-ART - conservação, documentação e gestão das primeiras manifestações de arte rupestre no Sudoeste da Península Ibérica: as grutas do Escoural e Maltravieso Sara Garcês / Hipólito Collado / José Julio García Arranz / Luiz Oosterbeek / António Carlos Silva / Pierluigi Rosina / Hugo Gomes / Anabela Borralheiro Pereira / George Nash / Esmeralda Gomes / Nelson Almeida / Carlos Carpetudo

523 Trabalhos de documentação de arte paleolítica realizados no âmbito do projeto PalæoCôa André Tomás Santos / António Fernando Barbosa / Luís Luís / Marcelo Silvestre / Thierry Aubry

537 Imagens fantasmagóricas, silhuetas elusivas: as figuras humanas na arte do Paleolítico Superior da região do Côa Mário Reis

$55^{1}$ Os motivos zoomórficos representados nas placas de tear de Vila Nova de São Pedro (Azambuja, Portugal) Andrea Martins / César Neves / José M. Arnaud / Mariana Diniz

571 Arte Rupestre do Monte de Góios (Lanhelas, Caminha). Síntese dos resultados dos trabalhos efectuados em 2007-2009 Mário Varela Gomes

599 Gravuras rupestres de barquiformes no Monte de S. Romão, Guimarães, Noroeste de Portugal Daniela Cardoso

613 Círculos segmentados gravados na Bacia do Rio Lima (Noroeste de Portugal): contributos para o seu estudo Diogo Marinho / Ana M.S. Bettencourt / Hugo Aluai Sampaio

631 Equídeos gravados no curso inferior do Rio Mouro, Monção (NW Portugal). Análise preliminar Coutinho, L.M. / Bettencourt, A.M.S / Sampaio, Hugo A.S

645 Paletas na Arte Rupestre do Noroeste de Portugal. Inventário preliminar Bruna Sousa Afonso / Ana M. S. Bettencourt / Hugo A. Sampaio 


\section{Pré-História}

661 O projeto Miño/Minho: balanço de quatro anos de trabalhos arqueológicos Sérgio Monteiro-Rodrigues / João Pedro Cunha-Ribeiro / Eduardo Méndez-Quintas / Carlos Ferreira / Pedro Xavier / José Meireles / Alberto Gomes / Manuel Santonja / Alfredo Pérez-González

677 A ocupação paleolítica da margem esquerda do Baixo Minho: a indústria lítica do sítio de Pedreiras 2 (Monção, Portugal) e a sua integração no contexto regional Carlos Ferreira / João Pedro Cunha-Ribeiro / Sérgio Monteiro-Rodrigues / Eduardo Méndez-Quintas / Pedro Xavier / José Meireles / Alberto Gomes / Manuel Santonja / Alfredo Pérez-González

693 O sítio acheulense do Plistocénico médio da Gruta da Aroeira Joan Daura / Montserrat Sanz / Filipa Rodrigues / Pedro Souto / João Zilhão

703 As sociedades neandertais no Barlavento algarvio: modelos preditivos com recurso aos SIG

Daniela Maio

715 A utilização de quartzo durante o Paleolítico Superior no território dos vales dos rios Vouga e Côa

Cristina Gameiro / Thierry Aubry / Bárbara Costa / Sérgio Gomes / Luís Luís / Carmen Manzano / André Tomás Santos

733 Uma perspetiva diacrónica da ocupação do concheiro do Cabeço da Amoreira (Muge, Portugal) a partir da tecnologia lítica Joana Belmiro / João Cascalheira / Célia Gonçalves

745 Novos dados sobre a Pré-história Antiga no concelho de Palmela. A intervenção arqueológica no sítio do Poceirão I

Michelle Teixeira Santos

757 Problemas em torno de Datas Absolutas Pré-Históricas no Norte do Alentejo Jorge de Oliveira

771 Povoamento pré-histórico nas áreas montanhosas do NO de Portugal: o Abrigo 1 de Vale de Cerdeira Pedro Xavier / José Meireles / Carlos Alves

783 Apreciação do povoamento do Neolítico Inicial na Baixa Bacia do Douro. A Lavra I (Serra da Aboboreira) como caso de estudo Maria de Jesus Sanches

797 O Processo de Neolitização na Plataforma do Mondego: os dados do Sector C do Outeiro dos Castelos de Beijós (Carregal do Sal)

João Carlos de Senna-Martinez / José Manuel Quintã Ventura / Andreia Carvalho / Cíntia Maurício

823 Novos trabalhos na Lapa da Bugalheira (Almonda, Torres Novas) Filipa Rodrigues / Pedro Souto / Artur Ferreira / Alexandre Varanda / Luís Gomes / Helena Gomes / João Zilhão

837 A pedra polida e afeiçoada do sítio do Neolítico médio da Moita do Ourives (Benavente, Portugal)

César Neves

857 Casal do Outeiro (Encarnação, Mafra): novos contributos para o conhecimento do povoamento do Neolítico final na Península de Lisboa.

Cátia Delicado / Carlos Maneira e Costa / Marta Miranda / Ana Catarina Sousa

873 Stresse infantil, morbilidade e mortalidade no sítio arqueológico do Neolítico Final/ Calcolítico ( $4^{\circ}$ e $3^{\circ}$ milénio a.C.) do Monte do Carrascal 2 (Ferreira do Alentejo, Beja) Liliana Matias de Carvalho / Sofia N. Wasterlain 
885 Come together: O Conjunto Megalítico das Motas (Monção, Viana do Castelo) e as expressões Campaniformes do Alto Minho Ana Catarina Basílio / Rui Ramos

899 Trabalhos arqueológicos no sítio Calcolítico da Pedreira do Poio Carla Magalhães / João Muralha / Mário Reis / António Batarda Fernandes

913 O sítio arqueológico de Castanheiro do Vento. Da arquitectura do sítio à arquitectura de um território João Muralha Cardoso

925 Estudo zooarqueológico das faunas do Calcolítico final de Vila Nova de São Pedro (Azambuja, Portugal): Campanhas de 2017 e 2018 Cleia Detry / Ana Catarina Francisco / Mariana Diniz / Andrea Martins / César Neves / José Morais Arnaud

943 As faunas depositadas no Museu Arqueológico do Carmo provenientes de Vila Nova de São Pedro (Azambuja): as campanhas de 1937 a 1967 Ana Catarina Francisco / Cleia Detry / César Neves / Andrea Martins / Mariana Diniz / José Morais Arnaud

959 Análise funcional de material lítico em sílex do castro de Vila Nova de S. Pedro (Azambuja, Portugal): uma primeira abordagem Rafael Lima

971 O recinto da Folha do Ouro 1 (Serpa) no contexto dos recintos de fossos calcolíticos alentejanos

António Carlos Valera / Tiago do Pereiro / Pedro Valério / António M. Monge Soares

\section{Proto-História}

987 Produção de sal marinho na Idade do Bronze do noroeste Português. Alguns dados para uma reflexão

Ana M. S. Bettencourt / Sara Luz / Nuno Oliveira / Pedro P. Simões / Maria Isabel C. Alves / Emílio Abad-Vidal

1001 A estátua-menir do Pedrão ou de São Bartolomeu do Mar (Esposende, noroeste de Portugal) no contexto arqueológico da fachada costeira de entre os rios Neiva e Cávado Ana M. S. Bettencourt / Manuel Santos-Estévez / Pedro Pimenta Simões / Luís Gonçalves

1015 O Castro do Muro (Vandoma/Baltar, Paredes) - notas para uma biografia de ocupação da Idade do Bronze à Idade Média

Maria Antónia D. Silva / Ana M. S. Bettencourt / António Manuel S. P. Silva / Natália Félix

1031 Do Bronze Final à Idade Média - continuidades e hiatos na ocupação de Povoados em Oliveira de Azeméis João Tiago Tavares / Adriaan de Man

1041 As faunas do final da Idade do Bronze no Sul de Portugal: leituras desde o Outeiro do Circo (Beja)

Nelson J. Almeida / Íris Dias / Cleia Detry / Eduardo Porfírio / Miguel Serra

1055 A Espada do Monte das Oliveiras (Serpa) - uma arma do Bronze Pleno do Sudoeste Rui M. G. Monge Soares / Pedro Valério / Mariana Nabais / António M. Monge Soares

1065 São Julião da Branca (Albergaria-a-Velha) - Investigação e valorização de um povoado do Bronze Final

António Manuel S. P. Silva / Paulo A. P. Lemos / Sara Almeida e Silva / Edite Martins de Sá

1083 Do castro de S. João ao Mosteiro de Santa Clara: notícia de uma intervenção arqueológica, em Vila do Conde Rui Pinheiro 
1095 O castro de Ovil (Espinho), um quarto de século de investigação - resultados e questões em aberto

Jorge Fernando Salvador / António Manuel S. P. Silva

1111 O Castro de Salreu (Estarreja), um povoado proto-histórico no litoral do Entre Douro e Vouga

Sara Almeida e Silva / António Manuel S. P. Silva / Paulo A. P. Lemos / Edite Martins de Sá

1127 Castro de Nossa Senhora das Necessidades (Sernancelhe): uma primeira análise artefactual Telma Susana O. Ribeiro

${ }_{1141}$ A cividade de Bagunte. O estado atual da investigação Pedro Brochado de Almeida

1153 Zoomorfos na cerâmica da Idade do Ferro no NW Peninsular: inventário, cronologias e significado Nuno Oliveira / Cristina Seoane

1163 Vasos gregos em Portugal: diferentes maneiras de contar a história do intercâmbio cultural na Idade do Ferro

Daniela Ferreira

1175 Os exotica da necrópole da Idade do Ferro do Olival do Senhor dos Mártires (Alcácer do Sal) no seu contexto regional

Francisco B. Gomes

\section{Antiguidade Clássica e Tardia}

1191 O uso de madeira como combustível no sítio da Quinta de Crestelos (Baixo Sabor): da Idade do Ferro à Romanização Filipe Vaz / João Tereso / Sérgio Simões Pereira / José Sastre / Javier Larrazabal Galarza / Susana Cosme / José António Pereira / Israel Espi

1207 Cultivos de Época Romana no Baixo Sabor: continuidade em tempos de mudança? João Pedro Tereso / Sérgio Simões Pereira / Filipe Santos / Luís Seabra / Filipe Vaz

1221 A casa romana na Hispânia: aplicação dos modelos itálicos nas províncias ibéricas Fernanda Magalhães / Diego Machado / Manuela Martins

1235 As pinturas murais romanas da Rua General Sousa Machado, n. ${ }^{5}$ 1, Chaves José Carvalho

1243 Trás do Castelo (Vale de Mir, Pegarinhos, Alijó) - Uma exploração agrícola romana do Douro

Tony Silvino / Pedro Pereira

1255 A sequência de ocupação no quadrante sudeste de Bracara Augusta: as transformações de uma unidade doméstica Lara Fernandes / Manuela Martins

1263 Os Mosaicos com decoração geométrica e geométrico-vegetalista dos sítios arqueológicos da área do Conuentus Bracaraugustanus. Novas abordagens quanto à conservação, restauro, decoração e datação Maria de Fátima Abraços / Licínia Wrench

1277 “Casa Romana” do Castro de São Domingos (Cristelos, Lousada): Escavação, Estudo e Musealização Paulo André de P. Lemos

1291 A arqueobotânica no Castro de Guifões (Matosinhos, Noroeste de Portugal): O primeiro estudo carpológico

Luís Seabra / Andreia Arezes / Catarina Magalhães / José Varela / João Pedro Tereso 
1305 Um Horreum Augustano na Foz do Douro (Monte do Castelo de Gaia, Vila Nova de Gaia) Rui Ramos

1311 Ponderais romanos na Lusitânia: padrões, formas, materiais e contextos de utilização Diego Barrios Rodríguez

1323 Um almofariz centro-itálico na foz do Mondego

Marco Penajoia

1335 Estruturas romanas de Carnide - Lisboa Luísa Batalha / Mário Monteiro / Guilherme Cardoso

1347 O contexto funerário do sector da "necrópole NO" da Rua das Portas de S. Antão (Lisboa): o espaço, os artefactos, os indivíduos e a sua interconectividade na interpretação do passado Sílvia Loja, José Carlos Quaresma, Nelson Cabaço, Marina Lourenço, Sílvia Casimiro, Rodrigo Banha da Silva, Francisca Alves-Cardoso

${ }_{1361}$ Povoamento em época Romana na Amadora - resultados de um projeto pluridisciplinar Gisela Encarnação / Vanessa Dias

1371 A Arquitectura Residencial em Mirobriga (Santiago do Cacém): contributo a partir de um estudo de caso Filipe Sousa / Catarina Felício

${ }_{1385}$ O fim do ciclo. Saneamento e gestão de resíduos nos edifícios termais de Mirobriga (Santiago do Cacém)

Catarina Felício / Filipe Sousa

1399 Balsa, Topografia e Urbanismo de uma Cidade Portuária Vítor Silva Dias / João Pedro Bernardes / Celso Candeias / Cristina Tété Garcia

1413 No Largo das Mouras Velhas em Faro (2017): novas evidências da necrópole norte de Ossonoba e da sua ocupação medieval Ricardo Costeira da Silva / Paulo Botelho / Fernando Santos / Liliana Nunes

1429 Instrumentos de pesca recuperados numa fábrica de salga em Ossonoba (Faro) Inês Rasteiro / Ricardo Costeira da Silva / Paulo Botelho

1439 A Necrópole Romana do Eirô, Duas Igrejas (Penafiel): intervenção arqueológica de 2016 Laura Sousa / Teresa Soeiro

1457 Ritual, descarte ou afetividade? A presença de Canis lupus familiaris na Necrópole Noroeste de Olisipo (Lisboa)

Beatriz Calapez Santos / Sofia Simões Pereira / Rodrigo Banha da Silva / Sílvia Casimiro / Cleia Detry / Francisca Alves Cardoso

1467 Dinâmicas económicas em Bracara na Antiguidade Tardia Diego Machado / Manuela Martins / Fernanda Magalhães / Natália Botica

1479 Cerâmicas e Vidros da Antiguidade Tardia do Edifício sob a Igreja do Bom Jesus (Vila Nova de Gaia) Joaquim Filipe Ramos

1493 Novos contributos para a topografia histórica de Mértola no período romano e na Antiguidade Tardia Virgílio Lopes

\section{8. Época Medieval}

1511 Cerâmicas islâmicas no Garb setentrional "português": algumas evidências e incógnitas Constança dos Santos / Helena Catarino / Susana Gómez / Maria José Gonçalves / Isabel Inácio / Gonçalo Lopes / Jacinta Bugalhão / Sandra Cavaco / Jaquelina Covaneiro / Isabel Cristina Fernandes / Ana Sofia Gomes 
1525 Contributo para o conhecimento da cosmética islâmica, em Silves, durante a Idade Média Rosa Varela Gomes

1537 Yábura e o seu território - uma análise histórico-arqueológica de Évora entre os séculos VIII-XII José Rui Santos

1547 A encosta sul do Castelo de Palmela - resultados preliminares da escavação arqueológica Luís Filipe Pereira / Michelle Teixeira Santos

1559 A igreja de São Lourenço (Mouraria, Lisboa): um conjunto de silos e de cerâmica medieval islâmica

Andreia Filipa Moreira Rodrigues

1571 O registo material de movimentações populacionais no Médio Tejo, durante os séculos XII-XIII. Dois casos de "sunken featured buildings", nos concelhos de Cartaxo e Torres Novas Marco Liberato / Helena Santos / Nuno Santos

1585 O nordeste transmontano nos alvores da Idade média. Notas para reflexão Ana Maria da Costa Oliveira

1601 Sepulturas escavadas na rocha do Norte de Portugal e do Vale do Douro: primeiros resultados do Projecto SER-NPVD

Mário Jorge Barroca / César Guedes / Andreia Arezes / Ana Maria Oliveira

1619 "Portucalem Castrum Novum" entre o Mediterrâneo e o Atlântico: o estudo dos materiais cerâmicos alto-medievais do arqueossítio da rua de D. Hugo, nํ. 5 (Porto) João Luís Veloso

1627 A Alta Idade Média na fronteira de Lafões: notas preliminares sobre a Arqueologia no Concelho de Vouzela

Manuel Luís Real / Catarina Tente

1641 Um conjunto cerâmico medieval fora de portas: um breve testemunho aveirense Susana Temudo

${ }_{1651}$ Os Lóios do Porto: uma perspetiva integrada no panorama funerário da Baixa Idade Média à Época Moderna em meios urbanos em Portugal

Ana Lema Seabra

1659 O Caminho Português Interior de Santiago como eixo viário na Idade Média Pedro Azevedo

1665 Morfologia Urbana: Um exercício em torno do Castelo de Ourém André Donas-Botto / Jaqueline Pereira

1677 Intervenção arqueológica na Rua Marquês de Pombal/Largo do Espírito Santo (Bucelas, Loures)

Florbela Estêvão / Nathalie Antunes-Ferreira / Dário Ramos Neves / Inês Lisboa

1691 O Cemitério Medieval do Poço do Borratém e a espacialidade funerária na cidade de Lisboa Inês Belém / Vanessa Filipe / Vasco Noronha Vieira / Sónia Ferro / Rodrigo Banha da Silva

1705 Um Espaço Funerário Conventual do séc. XV em Lisboa: o caso do Convento de São Domingos da Cidade Sérgio Pedroso / Sílvia Casimiro / Rodrigo Banha da Silva / Francisca Alves Cardoso

\section{9. Época Moderna e Contemporânea}

1721 Arqueologia Moderna em Portugal: algumas reflexões críticas em torno da quantificação de conjuntos cerâmicos e suas inferências históricas e antropológicas Rodrigo Banha da Silva / André Bargão / Sara da Cruz Ferreira

1733 Faianças de dois contextos entre os finais do século XVI e XVIII do Palácio dos Condes de Penafiel, Lisboa

Martim Lopes / Tomás Mesquita 
1747 Um perfil de consumo do século XVIII na foz do Tejo: O caso do Mercado da Ribeira, Lisboa Sara da Cruz Ferreira / Rodrigo Banha da Silva / André Bargão

1761 Os Cachimbos dos Séculos XVII e XVIII do Palácio Mesquitela e Convento dos Inglesinhos (Lisboa)

Inês Simão / Marina Pinto / João Pimenta / Sara da Cruz Ferreira / André Bargão / Rodrigo Banha da Silva

1775 "Tomar os fumos da erua que chamão em Portugal erua sancta». Estudo de Cachimbos provenientes da Rua do Terreiro do Trigo, Lisboa

Miguel Martins de Sousa / José Pedro Henriques / Vanessa Galiza Filipe

1787 Cachimbos de Barro Caulínitico da Sé da Cidade Velha (República de Cabo Verde)

Rodrigo Banha da Silva / João Pimenta / Clementino Amaro

1801 Algumas considerações sobre espólio não cerâmico recuperado no Largo de Jesus (Lisboa) Carlos Boavida

1815 Adereços de vidro, dos séculos XVI-XVIII, procedentes do antigo Convento de Santana de Lisboa (anéis, braceletes e contas)

Joana Gonçalves / Rosa Varela Gomes / Mário Varela Gomes

1837 Da ostentação, luxo e poder à simplicidade do uso quotidiano: arqueologia e simbologia de joias e adornos da Idade Moderna Portuguesa Jéssica Iglésias

1849 Os amuletos em Portugal - dos objetos às superstições: o coral vermelho Alexandra Vieira

1865 Cerâmicas de Vila Franca de Xira nos séculos XV e XVI Eva Pires

1879 «Não passa por teu o que me pertence». Marcas de individualização associadas a faianças do Convento de Nossa Senhora de Aracoeli, Alcácer do Sal Catarina Parreira / Íris Fragoso / Miguel Martins de Sousa

1891 Cerâmica de Leiria: alguns focos de produção

Jaqueline Pereira / André Donas-Botto

1901 Os Fornos na Rua da Biquinha, em Óbidos Hugo Silva / Filipe Oliveira

1909 A casa de Pêro Fernandes, contador dos contos de D. Manuel I: o sítio arqueológico da Silha do Alferes, Seixal (século XVI) Mariana Nunes Ferreira

1921 O Alto da Vigia (Sintra) e a vigilância e defesa da costa Alexandre Gonçalves / Sandra Santos

1937 O contexto da torre sineira da Igreja de Santa Maria de Loures Paulo Calaveira / Martim Lopes

1949 A Necrópole do Hospital Militar do Castelo de São Jorge e as práticas funerárias na Lisboa de Época Moderna Susana Henriques / Liliana Matias de Carvalho / Ana Amarante / Sofia N. Wasterlain

1963 SAND - Sarilhos Grandes Entre dois Mundos: o adro da Igreja e a Paleobiologia dos ossos humanos recuperados

Paula Alves Pereira / Roger Lee Jesus / Bruno M. Magalhães

1975 Expansão urbana da vila de Cascais no século XVII e XVIII: a intervenção arqueológica na Rua da Vitória no 15 a 17

Tiago Pereira / Vanessa Filipe

1987 Novos dados para o conhecimento do Urbanismo de Faro em época Moderna Ana Rosa 
1995 Um exemplo de Arqueologia Urbana em Alcoutim: o Antigo Edifício dos CTT Marco Fernandes / Marta Dias / Alexandra Gradim / Virgílio Lopes / Susana Gómez Martínez

2007 Palácio dos Ferrazes (Rua das Flores/Rua da Vitória, Porto): a cocheira de Domingos Oliveira Maia

Francisco Raimundo

2021 As muitas vidas de um edifício urbano: História, Arqueologia e Antropologia no antigo Recreatório Paroquial de Penafiel Helena Bernardo / Jorge Sampaio / Marta Borges

2035 O convento de Nossa Senhora da Esperança de Ponta Delgada: o contributo da arqueologia para o conhecimento de um monumento identitário João Gonçalves Araújo / N’Zinga Oliveira

2047 Arqueologia na ilha do Corvo... em busca da capela de Nossa Senhora do Rosário Tânia Manuel Casimiro / José Luís Neto / Luís Borges / Pedro Parreira

2059 Perdidos à vista da Costa. Trabalhos arqueológicos subaquáticos na Barra do Tejo Jorge Freire / José Bettencourt / Augusto Salgado

2071 Arqueologia marítima em Cabo Verde: enquadramento e primeiros resultados do projecto CONCHA

José Bettencourt / Adilson Dias / Carlos Lima / Christelle Chouzenoux / Cristóvão Fonseca / Dúnia Pereira / Gonçalo Lopes / Inês Coelho / Jaylson Monteiro / José Lima / Maria Eugénia Alves / Patrícia Carvalho / Tiago Silva

2085 Trabalhos arqueológicos na Cidade Velha (Ribeira Grande de Santiago, Cabo Verde): reflexões sobre um projecto de investigação e divulgação patrimonial André Teixeira / Jaylson Monteiro / Mariana Mateus / Nireide Tavares / Cristovão Fonseca / Gonçalo C. Lopes / Joana Bento Torres / Dúnia Pereira / André Bargão / Aurélie Mayer / Bruno Zélie / Carlos Lima / Christelle Chouzenoux / Inês Henriques / Inês Pinto Coelho / José Lima / Patrícia Carvalho / Tiago Silva

2103 A antiga fortificação de Quelba / Khor Kalba (E.A.U.). Resultados de quatro campanhas de escavações, problemáticas e perspectivas futuras Rui Carita / Rosa Varela Gomes / Mário Varela Gomes / Kamyar Kamyad

2123 Colónias para homens novos: arqueologia da colonização agrária fascista no noroeste ibérico Xurxo Ayán Vila / José Mạ . Señorán Martín 


\title{
A CASA ROMANA NA HISPÂNIA: APLICAÇÃO DOS MODELOS ITÁLICOS NAS PROVÍNCIAS IBÉRICAS
}

\author{
Fernanda Magalhães ${ }^{1}$, Diego Machado², Manuela Martins ${ }^{3}$
}

\begin{abstract}
RESUMO
O modelo de casa itálica foi difundido desde os finais do século II a.C., a partir do Levante ibérico, expandindo-se progressivamente para os territórios do interior da Península Ibérica, acabando por se generalizar no contexto das novas fundações urbanas que terão lugar após o fim das guerras cantábricas. Assim, é possível constatar que, a partir de Augusto, as diferentes regiões da Hispânia vão conhecer um amplo processo de estandardização cultural das habitações urbanas de elite, em que se reconhece a disseminação de uma linguagem arquitetónica, bastante flexível, que tira partido de um léxico de formas, originariamente desenvolvido em Itália, ainda que alguns dos seus traços remontem às tradições helenísticas do Oriente. Inicia-se um processo sem precedentes de ampla estandardização cultural.
\end{abstract}

Palavras-chave: Hispânia, Arquitetura privada, Domus, Vida quotidiana.

\begin{abstract}
The model of the italic house was spread since the end of the 2 st century BC, from the Iberian Levant, gradually expanding into the territories of the interior of the Iberian Peninsula, eventually becoming generalized in the context of the new urban foundations that will take place after the end of the Cantabrian wars. Thus, it is possible to verify that, from Augustus, the different regions of Hispania will know a broad process of cultural standardization of elite urban dwellings, in which the dissemination of an architectural language, quite flexible, is recognized, which takes advantage of a lexicon of forms, originally developed in Italy, although some of its traits go back to the Hellenistic traditions of the East. An unprecedented process of broad cultural standardization begins.
\end{abstract}

Keywords: Hispania, Private architecture, Domus, Daily life.

\section{INTRODUÇÃO}

A partir de finais do século II a.C dissemina-se o modelo de casa itálica, iniciando-se o processo no Levante ibérico, ampliando-se progressivamente para os territórios do interior da Península Ibérica, acabando por se generalizar no contexto das novas fundações urbanas que terão lugar após o fim das guerras cantábricas. A partir de Augusto, as diferentes regiões da Hispânia vão experimentar um largo processo de estandardização cultural das habitações urbanas de elite, em que se reconhece a dissemina- ção de uma linguagem arquitetónica bastante flexível, que tira partido de um léxico de formas originariamente desenvolvido em Itália, ainda que alguns dos seus traços remontem às tradições helenísticas do Oriente. Inicia-se um processo sem precedentes de ampla estandardização cultural, assente na criação de uma linguagem franca, adaptável e sedutora, capaz de atrair as elites locais. Essa linguagem passa pelo urbanismo e pela arquitetura, atingindo os bens consumíveis, desde os alimentos a uma gama variada de produtos.

A disseminação alargada da linguagem arquitetó-

\footnotetext{
1. Unidade de Arqueologia da Universidade do Minho, Lab2PT, UMinho; fmagalhaes@uaum.uminho.pt

2. Unidade de Arqueologia da Universidade do Minho, Lab2PT, UMinho; diegosfmachado@gmail.com

3. Professora Catedrática da UMinho e investigadora do Lab2PT; mmmartins@uaum.uminho.pt
} 
nica itálica, aplicada às casas, quer nos contextos das novas fundações urbanas, de que são exemplo Bracara Augusta e Complutum, na Tarraconense, ou Augusta Emerita, na Lusitânia, quer em núcleos urbanos que se desenvolvem a partir de povoados indígenas, como acontece com Conimbriga, cidade da Lusitânia, contribuiu para consolidar os espaços urbanos, mas também a sociedade provincial, na qual emerge uma nova elite hispano-romana, que reelabora os aspetos essenciais das funções sociais associadas aos espaços da casa de prestígio. Nelas se incluem os átrios e os vestíbulos, destinados a impressionar a clientela, ou os jardins porticados, envolvidos por salões de receção, os quais se tornam espaços que transmitem a identidade dos elementos de elite de qualquer cidade, fossem eles originários da Itália, ou descendentes de indígenas.

As domus passam então a estruturar-se em função de um conjunto de espaços que se organizam em torno de áreas abertas (atria), ou ajardinadas (peristyla), independentemente da sua dimensão e configuração, aspetos que resultavam da sua adequação à topografia das cidades e da riqueza dos seus proprietários ou das suas atividades quotidianas. Usando um conjunto de exemplos de casas de várias cidades procuraremos demonstrar como as domus, para além de servirem às necessidades de residência da família, representam, na verdade, um conjunto de espaços arquitetónicos interrelacionáveis que transmitem a identidade de quem neles residia.

\section{AS PRIMEIRAS CASAS DE INSPIRAÇÃO ITÁLICA}

O início do processo de conquista romana da Hispania esteve intimamente inserido no contexto da Segunda Guerra Púnica, desencadeada pelo avanço de Roma sobre a fronteira previamente estabelecida com Cartago, na região definida pelo rio Ebro. A defesa da cidade de Sagunto acabaria por resultar num conflito que se arrastaria por dois séculos e que só terminaria em 19 a.C., encerrando o ciclo das guerras cantábricas, com a vitória romana e subsequente anexação da Península Ibérica ao Império romano (Eckstein, 2006, pp. 170-176).

A influência de Roma sobre as cidades do sul da Península, bem como sobre as populações hispânicas, situadas a norte e sul do Ebro, começou a partir dos inícios do século III a.C. Nos séculos subsequentes, o interior peninsular foi conquistado pelos generais romanos e a Hispania foi incluída no orbis romanorum, o que conduziu a uma reorganização administrativa de toda a Península Ibérica, através da configuração de três províncias, a Lusitania, no sudoeste ibérico, onde hoje estão situados os territórios portugueses a sul do Douro, a Estremadura espanhola e parte da província de Salamanca, a Baetica, localizada no extremo sul peninsular, ocupando, sensivelmente, a atual Andaluzia e, por fim, a Tarraconense, que integrava as demais regiões peninsulares.

O ritmo do avanço romano no território da Hispânia também se manifesta na influência dos modelos arquitetónicos itálicos nas casas dos aglomerados habitacionais peninsulares, maioritariamente de fundação indígena. Com efeito, o contacto com os militares e mercadores romanos nas regiões levantinas e meridionais foi bastante precoce desencadeando uma romanização mais antiga, cuja expressão, a nível da arquitetura doméstica, se encontra bem documentada nas cidades dispostas ao longo da costa mediterrânica e nas margens do rio Ebro. Nesses locais é possível perceber a gradativa adaptação das plantas e dos espaços das habitações, com clara incorporação da linguagem arquitetónica de origem itálica, cujos resultados compositivos assinalam a versatilidade dos modelos construtivos locais, que representam um inevitável resultado de processos de forte interação cultural entre indígenas, Fenícios, Gregos e Púnicos. A gramática itálica nos espaços das domus é reconhecida com a disposição dos compartimentos em redor de um atrium, cuja implantação, nalguns casos, parece estar relacionada com a evolução de um pátio, utilizado para captação de água, bem como com o recurso ao uso do opus signinum e do opus tessellatum no revestimento dos pavimentos de algumas salas.

Em Ampurias identificaram-se um conjunto de habitações que retratam bem a progressiva incorporação de elementos itálicos nas plantas das casas desde de meados do século II a.C.. Nessa cidade as unidades domésticas mais antigas estão representadas por construções muito simples, designados por tabernae, com planta retangular, internamente divididas em dois compartimentos. O desenvolvimento desse tipo de habitação acontece com a implantação de um terceiro compartimento, formalizando-se uma planta em 'L', cujos vestígios arqueológicos permitem sugerir a existência de pátios (Mar \& Ruiz de Arbulo, 1993, pp. 349-360). Todavia, esses pátios viriam a dar origem aos atria itálicos, os quais se 
assumem como o elemento ordenador dos compartimentos que se desenvolvem em seu redor. Por outro lado, atesta-se igualmente uma rica variedade de plantas associadas a esse espaço, que tanto podia ocupar numa posição central como lateral, enquadrando-se em diferentes tipologias, das quais são exemplos os atria toscanos, os tetrástilos, os coríntios e testudinados, o que expressa bem a variedade de linguagens arquitetónicas, cuja gramática foi estimulada pelos ricos colonos que habitavam a cidade de Ampúrias em época tardo-republicana (Mar \& Ruiz de Arbulo, 1993, pp. 361-380).

Das cidades articuladas com grandes vales de rios salientamos Celsa, colónia romana fundada no baixo vale do Ebro, em meados do século I a.C,. por Marcus Emilius Lepidus, destinada a albergar veteranos das legiões. Nesta cidade, os exemplares de casas configuram diferentes tipologias de espaços centrais abertos, assinalando claras influências itálicas, como as casas de atrium toscano, testudinado e as casas de pátio, alguns dos quais porticados, que, para além de reproduzirem na Hispania esse tipo de espaços, proveniente dos modelos habitacionais difundidos na Península Itálica, apresentam também outros compartimentos relacionados com as atividades diárias próprias de uma casa de elite, como seria o caso do fauces, destinado à prática da salutatio, ou o tablinum, onde o paterfamilias geria os seus negócios (Beltrán Lloris, 1991, pp. 135-151).

Em termos gerais, podemos constatar que a arquitetura doméstica das cidades tardo-republicanas do sul da Península Ibérica revela uma marcada preferência pelos modelos utilizados nas cidades da Itália. Inicialmente, os espaços das casas que assumiram funções de ordenação e distribuição das demais áreas do interior das residências foram os pátios, alguns dos quais com funções de captação de água, exibindo caraterísticas e dimensões bastante variadas. Parte desses pátios foram transformados em atria, com tipologias que reproduzem a grande variedade de soluções observadas em Itália, desde os átrios toscanos, ou testudinados, até aos mais elaborados, que recorriam a colunatas tetrástilas, ou hexástilas, estes também chamados coríntios. Ainda que com expressão mais modesta, cabe referir que, no período tardo-republicano, o peristylium também se foi afirmando como um elemento de cariz itálico, introduzido nas arquiteturas domésticas hispânicas.

\section{A DIFUSÃO DA LINGUAGEM ARQUITETÓNICA ITÁLICA NOS CONTEXTOS INDÍGENAS}

Nas cidades da Península Ibérica a linguagem arquitetónica itálica foi aplicada em crescente escala ao longo do período tardo-republicano, em contextos habitacionais das cidades de Ampurias, Badalona, Tarraco, ou Celsa, sendo os proprietários das habitações presumíveis cidadãos romanos, ou libertos destacados para esses locais, como parece acontecer com a 'Casa C', na Ínsula I, de Celsa, cujo dono terá sido um L. Licinius At(ico), talvez um liberto de $L$. Licinius Sura, um magistrado monetário daquela cidade (Beltrán Lloris, 1991, pp. 148-149).

A difusão da linguagem arquitetónica itálica foi identicamente observada noutros aglomerados de origem diversa, mas que acolheram populações de origem romana, os quais acabaram por influenciar o modo de vida e os gostos das comunidades indígenas. Esse foi o caso dos povoados de origem pré-romana, onde habitavam populações locais, cuja relação com Roma durante a República nem sempre foi pacífica, quer na área ibérica da Península, quer na chamada área céltica. Trata-se de duas regiões culturais que apresentam identidades diferenciadas e comportamentos distintos na sua relação com Roma. Logo, na área ibérica incluem-se alguns povos com um longo historial de comunicação com o litoral mediterrânico, enquanto a zona céltica do interior da Península, ou da área litoral norte atlântica e cantábrica se caracteriza pela sua tardia relação com Roma, em grande medida apenas conseguida após as campanhas de Brutus, em 137 a.C. e, nalguns casos, após as Guerras Cantábricas, depois de 19 a.C., que assinalou o fim do longo ciclo da conquista da Hispânia.

A influência mediterrânica sobre as comunidades do sul e do sudeste da Península Ibérica acabaria por ajudar a produzir a grande família de sociedades ibéricas, enquanto as influências continentais, que penetraram no interior da Península e se difundiram ao longo das regiões atlânticas, viriam a dar origem a uma outra região, onde se reconhecem traços culturais comuns aos territórios centro europeus. Em resultado dessas duas influências constitui-se um mosaico de etnias e grupos culturais, que apresentam diferentes graus de complexidade, tendo cada grupo desenvolvido uma relação particular com Roma, por vezes através de enfrentamentos militares e, noutros casos, por via de pactos de paz. O grau de inte- 
gração de cada grupo no grande sistema económico e sociopolítico romano determinou uma maior aceitação dos modelos culturais importados da Itália. Neste sentido, a casa constitui, um precioso indicador cultural que nos mostra o modo como atuaram as elites dos diferentes povos indígenas e as condições socioculturais e económicas que acompanharam a sua progressiva integração no sistema romano.

Desde os primeiros momentos da conquista romana as populações locais exerceram um papel deveras importante no próprio domínio romano da Hispânia, seja pela sua aceitação inicial, ou após conflitos bélicos, desse domínio, ou pela associação das suas elites a Roma, tornando-se aliadas e com claros interesses em conseguir manter as suas posições de destaque, através da ocupação de cargos políticos, administrativos, económicos e religiosos, enquadrados nas novas lógicas sociais que se foram impondo com a presença romana. Este processo fez-se acompanhar de um gradativo processo de alteração das habitações, que adotaram os modelos itálicos com a consequente reprodução do léxico arquitetónico das casas de elite tardo-republicanas (Gros, 2006).

Em conjunto com o desenvolvimento das soluções locais de habitações dos povoados da Idade do Ferro da Península Ibérica, observam-se mudanças no modo de construir e organizar as casas, que adotam os modelos produzidos em Itália, oferecendo paralelos e exemplos nas cidades romanas de toda a Hispania.

O povoado de 'La Caridad', em Caminreal, Teruel, constitui um bom exemplo do processo assinalado, fornecendo importantes dados sobre a assimilação dos modelos itálicos pelas populações locais. Implantado nas proximidades do rio Jiloca, ocupa uma plataforma pouco elevada, delimitada por acidentes naturais, o que permitia a aplicação de modelos urbanísticos de tipo ortogonal sem grandes problemas, para além de possuir uma localização privilegiada para o escoamento da produção, que era feito pelo leito da via fluvial que desaguava no rio Jalón, um afluente do Ebro (Herce San Miguel \& alii, 1991, p. 82). Destacamos em 'La Caridad' a chamada 'Casa de Likine', uma habitação com cerca de $915 \mathrm{~m}^{2}$ que se estruturava em torno de um pátio central porticado de grandes dimensões, ocupando cerca de $1 / 4$ do tamanho total do lote, a partir do qual se tinha acesso a todos os demais compartimentos (Herce San Miguel \& alii, 1989).

Em Azaila, também na região de Teruel, existe um outro povoado ibérico que sofreu influência direta dos modelos itálicos nas suas habitações, logo após a sua conquista. Povoado fundado no século VII a.C., situado nas proximidades do rio Ebro, que terá uma vitalidade pujante até ao século I a.C. (Beltrán Lloris, 1976). Do conjunto das suas residências, destacamos a que é designada por $2 \mathrm{D}$, que corresponde à maior habitação identificada no povoado, estruturada em função de um amplo pátio central, que era acedido a partir de um uestibulum, cujo pavimento foi preservado na sua totalidade e apresenta um lajeado formado por placas de arenito (Beltrán Lloris, 1991, pp. 132-133).

Por sua vez, o NO peninsular que foi tardiamente integrado no Império, em 19 a.C., o que poderá ter contribuído para que nessa região a Idade do Ferro tenha perdurado até aos finais do I século a.C., situação que claramente proporcionou diferentes realidades sociais, políticas, económicas e urbanísticas, as quais podem ser agrupadas grosso modo na chamada 'Cultura Castreja' (Silva, 1986), com as devidas e necessárias ressalvas à aplicação desse termo, conforme vem sendo sugerido por vários autores (Martins, 1990; González Ruibal, 2006-2007; Cruz, 2018).

A Arqueologia demonstrou a existência de grandes assimetrias culturais entre estes grupos, destacando-se claramente um maior desenvolvimento da região meridional, correspondente à Gallaecia bracarense, onde no último século antes da nossa era se desenvolveram grandes povoados, tipo oppida, que funcionavam como lugares centrais e controlavam povoados mais pequenos, muitos dos quais ligados à exploração agropecuária intensiva dos vales (Martins, 1990). Logo, pode considerar-se que as assimetrias regionais do NO peninsular se aprofundam com a expedição de Decimus Iunius Brutus ao território situado entre o rio Minho e o Douro, que colocou a região sob controlo romano, embora sem ocupação militar, facilitando a relação desses territórios com as populações mais romanizadas do sul da Península Ibérica. Essas ligações terão potenciado o original desenvolvimento da fachada ocidental dessa região, ao longo do século I a.C., caracterizado pela emergência de um povoamento encabeçado por oppida, com sistemas defensivos complexos e uma forte concentração populacional, os quais possuíam sempre uma ampla visibilidade sobre o território envolvente, no qual pontuavam outros povoados dependentes. Internamente esses grandes povoados organizavam-se segundo uma estrutura viária 
ortogonal, que dividia o espaço em quarteirões, dentro dos quais se erguiam vários complexos residenciais, compostos por conjuntos de construções, unidas através de pátios lajeados (Silva, 1986). Estes grandes povoados, que chegavam a atingir vários hectares, possuíam equipamentos públicos, entre os quais se destacam as casas do conselho (Lemos, 2009; Cruz, 2015) e os balneários rituais (Gonzalez Ruibal, 2004; Silva \& Machado, 2007).

No noroeste peninsular os povoados fortificados mais antigos tiveram origem no Bronze Final e surgem na região meridional, precisamente aquela que será sempre mais influenciada pelos impulsos civilizacionais e tecnológicos do Mediterrâneo. No entanto, poucos são os povoados extensamente escavados, suscetíveis de revelar boas sequências de ocupação e os que foram muito escavados, foram-no, quase sempre, sem grandes preocupações metodológicas. Assim acontece com um dos mais conhecidos povoados fortificados do NO peninsular, a Citânia de Briteiros, em Guimarães, que começou a ser escavada no século XIX (Cruz, 2018). Trata-se de um povoado cuja origem remonta à Idade do Bronze Final, ou seja, aos inícios do Io milénio a.C., localizando-se no coração daquela que presumivelmente foi a área de domínio dos Bracari, tendo perdurado ocupado até pelo menos o século II. Neste verdadeiro oppidum da Idade do Ferro, sensivelmente a partir do século II a.C., ter-se-á configurado um verdadeiro centro urbano, onde se verifica uma alteração no modo de habitar, pois as áreas e construções residenciais passam a agregar-se em pequenos conjuntos delimitados por muros, formalizando unidades domésticas, que integravam casa, celeiro e outras construções destinadas a outras atividades domésticas mais especializadas, todas unificadas por pátios lajeados (Cruz, 2018, pp. 76-83).

$\mathrm{Na}$ Citânia de Briteiros, a influência mediterrânica e itálica faz-se sentir, sobretudo, no modo de organização do espaço dos povoados e de distribuição das suas habitações, pois os povoados tipo oppida são cruzados por um rudimentar sistema de eixos viários ortogonais, sistema que justificou uma reiterada discussão quanto à sua suposta datação romana. No entanto, sabemos hoje, com base nas recentes escavações de Gonçalo Cruz, que essa organização é anterior às Guerras Cantábricas e à fundação de Bracara Augusta, precedendo em várias décadas a integração da região dos Bracari no Império romano, pelo que o contexto em que o povoado se organizou, num modelo ortogonal, é perfeitamente indígena, ainda que influenciado por outras realidades peninsulares, quer do sul, quer da Meseta (Cruz, 2015).

No entanto, foi possível identificar duas casas, cuja configuração é completamente distinta da típica casa redonda castreja e que apresentam influências itálicas bem marcadas. Trata-se de duas casas de pátio central, uma localizada na área interior da primeira linha de muralhas e a outra situada entre esta fortificação e a segunda linha defensiva, cujos compartimentos são acedidos a partir dos pátios. Apesar de possuírem plantas bastante peculiares, com formas pouco regulares, sobretudo nos limites dos lotes, os compartimentos conformam retângulos com vértices bem marcados, sendo as suas funcionalidades de difícil interpretação. Destacamos a presença de uma espécie de uestibulum na casa localizada na parte mais alta do povoado, ainda que o mesmo apresente uma forma trapezoidal e não se encontre centrado com o pátio (Cruz, 2018).

O Castro do Monte Padrão, em Santo Tirso é outro povoado da Idade do Ferro do NO português, que regista uma grande longevidade, cuja implantação remonta aos inícios do Io milénio a.C., datando da Idade do Bronze Final (Martins, 1985), tendo sido abandonado em meados do século III. Este povoado situava-se na área de influência da Citânia de Sanfins, um oppidum também extensamente escavado, tal como a Citânia de Briteiros, que exerceria o controlo da área entre os rios Ave, a norte e Leça, a sul (Moreira, 2009, pp. 76-77). A uma fase avançada da ocupação do povoado, posterior à integração da região no Império romano, pertencerão duas construções de planta ortogonal, que foram construídas no topo do povoado, uma das quais seguramente correspondente a uma casa de modelo itálico, com pátio central. Anexo a essa habitação existia uma outra construção retangular. Trata-se de edifícios de grandes dimensões, com cerca de $77 \mathrm{om}^{2}$ e $8 \mathrm{oom}^{2}$, com espaços cuja funcionalidade, nalguns casos, é de difícil interpretação (Moreira, 2005).

A racionalização das formas construtivas e de reprodução da linguagem arquitetónica de matriz itálica por parte das elites indígenas da Península Ibérica, desde os inícios do processo de conquista da Hispania, ratifica a capacidade romana de atrair as populações locais e de integrá-las nos novos modelos económicos e sociais que se instauram com a conquista romana. É importante não esquecer que o conceito de romanização deve ser matizado pois, 
se é certo que existe uma receção e aceitação de modelos itálicos, ela faz-se acompanhar pelo aparecimento de uma nova base social formada por uma mistura de indígenas e de distintas categorias de pessoas que se fixam na Península Ibérica, atraídas pelas oportunidades do novo contexto sociopolítico de um vasto território, que passou a estar controlado integralmente por Roma. À medida que a conquista foi avançando e que os territórios foram sendo colocados sob controlo romano, soldados desmobilizados, populações itálicas e comerciantes foram engrossando a população das áreas integradas, contribuindo para a sua evolução e mudança cultural e para a adoção de novos hábitos que se difundiram num contexto de novas oportunidades para as populações de origem indígena negociarem novas identidades, designadamente através do uso de expressões arquitetónicas itálicas.

A ideia de 'casa' chegou de modo natural com emigrantes de Roma e da Itália, cuja expetativa seria a de conseguirem uma casa de prestígio na Hispânia romana, como expressão de reconhecimento de um estatuto social que não conseguiam alcançar nas suas terras de origem. Na verdade, nas cidades republicanas da costa mediterrânica, ou do vale do Bétis, tal como nas bem mais tardias cidades fundadas por Augusto no NO da Península Ibérica, confluíam os elementos que iriam formar uma nova elite de origem romano-itálica, que se viriam a misturar com os descendentes das antigas elites indígenas dos territórios que foram sendo progressivamente integrados. Assim, as casas romanas de elite das cidades do NO da Península Ibérica oferecem particularidades na interpretação dos modelos que chegam do âmbito mediterrânico, fundamentais para se compreender, de modo flexível, a adoção do peristilo porticado que se adapta às condições de cada casa e à natureza e protagonismo socioeconómico dos seus proprietários. Para melhor compreendermos esta realidade vamos tentar perceber o contexto de desenvolvimento das casas romanas no âmbito do urbanismo planificado, que se desenvolve a partir de Augusto, no quadro das cidades peninsulares de nova fundação.

\section{A CASA DA HISPÂNIA NO TEMPO DE AUGUSTO}

A linguagem arquitetónica criada em Itália destacava-se, sobretudo, pela imensa variedade de soluções que fornecia, o que resultou do facto do léxico for- mal que a compunha ter sido adaptado e reproduzido na Península Itálica durante séculos, pelo menos desde os finais do século IV a.C., o que possibilitou a formulação de diferentes soluções e o crescimento da gramática arquitetónica.

A casa latina mais antiga que se conhece corresponde às pequenas cabanas circulares, com teto de palha, no centro das quais havia uma abertura que permitia a saída do fumo proveniente da lareira, construções que eram características dos pagi, que compunham as ciuitates da Itália proto-histórica. Essas primeiras habitações já assinalavam aquilo que será fundamental no desenvolvimento das unidades domésticas itálicas e que se traduziu na diversidade de soluções para garantir a relação entre os espaços abertos e os fechados, as quais foram ganhando cada vez mais sofisticação (Gros, 2006; Pesando, 1997), resultando em casas que cresceram longitudinalmente, em redor de um espaço aberto, que viria a constituir-se com os átrios, onde o espaço aberto, o impluuium, assumia as funções de organizar os demais compartimentos e de armazenar água, através dos compluuia (Mar \& Ruiz de Arbulo, 1993, p. 361).

$\mathrm{Na}$ verdade, a capacidade que Roma revelou em adotar os modelos provenientes das cidades conquistadas, ao longo do período republicano, resultou na criação de um sistema identitário bastante diversificado, que lhe permitiu usar aquilo que lhe interessava e ignorar o que não queria, processo que deu origem a um léxico artístico e arquitetónico variado e adaptável (Zanker, 1998; Hölscher, 200o), bastante percetível quando olhamos especificamente para os espaços domésticos. De facto, a anexação da Magna Grécia nos inícios do século III a.C., bem como da Grécia e do Oriente helenístico em meados da centúria seguinte, forneceram um conjunto de modelos de espaços que atraíam os interesses das elites romanas por salas de representação cada vez mais sumptuosas, com a capacidade de impressionar e afirmar a relevância dos seus papéis sociais. As linguagens arquitetónicas oferecidas pelos territórios helenísticos e helenizados respondiam a esses interesses das elites romanas, estando os triclinia e os oeci incluídos no grande reportório de formas e soluções que podiam ser usados pelos membros destacados da aristocracia romana no momento da elaboração dos projetos das suas domus e da escolha de seus programas decorativos (Wallace-Hadrill, 2015, p. 183).

Atualmente, sabemos que as casas romanas eram distintas umas das outras, principalmente por con- 
ta das escolhas e dos gostos dos proprietários, existiam também alguns fatores externos, de natureza urbanística, que condicionavam os projetos, na hora de conceber os espaços do interior das habitações. Referimo-nos sobretudo a cidades em que o plano fundacional previa a implantação de quarteirões com pórticos na sua envolvente, as quais se encontram bem representadas na Hispania, constituindo um dos traços mais característicos da implantação romana de novas cidades. Trata-se de cidades com urbanismo ortogonal, com ruas porticadas, previstas logo desde a sua origem, de que são exemplo Augusta Emerita, Complutum e Bracara Augusta, onde a presença contínua do porticado condicionou o perímetro dos quarteirões, a regularidade da distribuição dos lotes, bem como a forma das casas. Porém, nas três cidades referidas verifica-se que os particulares chegaram a apropriar-se dos pórticos em momentos em que as casas necessitavam de mais área construída, como aconteceu em Bracara nos finais do século III/inícios do IV, quando, devido à promoção da cidade a capital da nova província da Galécia, as domus foram praticamente todas remodeladas (Martins $\mathbb{\&}$ alii, 2016). Esta apropriação é um sinal do desenvolvimento da vida urbana e do incremento das atividades no centro das cidades, cada vez mais densificado, que é característico de fases avançadas de ocupação. Naturalmente que, nas vias principais, nem sempre se regista esse processo de ocupação, criando-se deste modo uma hierarquia no sistema viário, com clara diferenciação entre as vias principais, que atravessavam as cidades, o que não acontecia com as vias secundárias e as ruas sem saída, que experimentaram um processo de privatização, ou a sua conversão num caminho de acesso a um grupo de propriedades privadas, geridas quase como uma via privada, sobre a qual se podia chegar a construir.

Na cidade de Conimbriga é possível observar o modo como as vias principais que conduziam ao foro, templos, ou ao exterior da cidade, foram monumentalizadas com a construção de pórticos e monumentos urbanos, algo que resulta da circunstância de corresponderem a eixos de circulação que canalizavam ou atraíam as atividades de natureza simbólica, como as procissões religiosas ou políticas, os cortejos, as festas e os sacrifícios. Estas vias atraíam também os fluxos comerciais e as atividades associadas com mercados, possuindo, normalmente, maior concentração de tabernae e locais comerciais e produtivos, que ocupavam a frente das casas, por onde se realizava o acesso aos locais de produção.

A colonia Augusta Emerita, capital da província da Lusitania, foi fundada em 25 a.C., nas margens do rio Anas, hoje chamado rio Guadiana, tendo sido povoada pelos soldados veteranos das legiões $\mathrm{V}$ Alaudae e X Gemina, ambas combatentes nas Guerras Cantábricas, sendo possível que um pequeno contingente de licenciados da legião XX tenha também participado na fundação da colónia (Faria, 1998). Os investimentos imperiais na construção dos edifícios públicos da cidade, dos quais destacamos o grande forum administrativo e alguns edifícios de espetáculo, como o teatro e o anfiteatro, ainda que construídos mais tarde, demonstram o grande interesse da casa imperial em garantir que a cidade prosperasse, o que parece estar associado com o controlo dos povos indígenas que habitavam aquela região, que define uma fronteira entre as tribos lusitanas e a Baetica, cuja produção oleica e piscícola era de grande importância para a economia romana. Outro motivo que parece ter sido estratégico para a implantação desta cidade relaciona-se com o controlo do rio Guadiana, uma importante via de comunicação, transporte e comércio entre o interior ibérico e o Atlântico, cuja foz se situava nas proximidades da costa dos centros exportadores da Baetica e não muito longe das Colunas de Hércules, atual Estreito de Gibraltar, que assinala o limite entre o oceano e o Mediterrâneo (Mateos Cruz, 2011, pp. 127-128).

Graças ao estudo dos vestígios provenientes das sucessivas décadas de escavações que se realizaram um pouco por toda a atual Mérida, sabemos que a cidade possuía um traçado ortogonal. Trata-se de uma malha com cardines e decumani retilíneos que conformam quarteirões quadrados e retangulares, denotando uma certa hierarquia dos espaços, a qual teve reflexo nas diferentes dimensões dos lotes das habitações que neles foram sendo implantados. Por outro lado, a colónia também apresenta alguns espaços que rompem com a matriz regular e ortogonal dos quarteirões, nos quais se instalaram grandes edifícios públicos, designadamente o forum e dois edifícios de espetáculos, que se apresentam contíguos: o teatro e o anfiteatro (Mateos Cruz, 1994-95, pp. 233-237).

Nas várias regiones de Augusta Emerita foram construídas habitações que apresentam variadíssimas plantas que documentam a utilização do amplo léxico arquitetónico de matriz itálica que já havia 
sido testado antes da fundação da cidade, noutros aglomerados urbanos do levante ibérico e da costa mediterrânica. Logo, foram reconhecidas casas que ostentavam espaços de distribuição e outras em que estes não existiam. Por outro lado, no que toca à tipologia desses espaços, foram individualizados tanto átrios como peristilos (Corrales Álvarez, 2014, pp. 193-202).

Em Augusta Emerita observa-se a uma adaptação dos modelos itálicos à forma das parcelas em que foram implantadas as casas. Assim acontece com a 'Casa 6 da Mouraria', localizada na regio III, a qual apresenta uma planta com forma quase quadrada, ocupando uma área de cerca de $100 \mathrm{om}^{2}$, metade da qual foi reservada a tabernae abertas ao cardo que corria a nascente da casa. Tendo em conta o espaço reduzido onde esta habitação foi implantada, parece aceitável admitir que possuía um segundo piso. Cabe também destacar a adequação dos espaços internos da casa em relação à forma dos lotes. Esses espaços seriam tendencialmente quadrados, como acontece com o peristilo, que possui três colunas em cada lado do jardim, o que lhe confere uma grande regularidade também reproduzida no ambulacrum. Nas reformas posteriores, a habitação avançou sobre o pórtico adjacente ao decumanus, localizado a norte, o que permitiu a ampliação do espaço interno da casa e a instalação de um balneário (Corrales Álvarez, 2014, pp. 837-840). O avanço das casas sobre os pórticos, resultando na privatização de um espaço que anteriormente era público, está patente em diversas casas da colonia, estando sobretudo bem documentado na área da Mouraria, onde algumas das habitações avançaram além dos passeios cobertos, tendo ocupado parte das vias ou mesmo encerrando-as (Sánchez Barrero, 2007).

A "Casa do Mitreo" foi implantada na regio VIII, ficando localizada extramuros, fora da malha urbana ortogonal, o que justifica que a sua planta seja bastante distinta das demais conhecidas, possuindo dimensões e uma morfologia que fogem por completo ao modelo urbano emeritense. Atualmente, não se conhecem os limites da casa, embora saiba-se que ela ocupava bem mais de $1500 \mathrm{~m}^{2}$ e que estaria organizada pelo menos em três espaços de distribuição, sendo um deles representado por um atrium e os outros por dois peristilos. O uso da área disponível para a construção denota a capacidade do proprietário investir em salas de receção e numa rica decoração, composta por pavimentos com mosaicos e paredes decoradas com pinturas, bem como na engenhosa articulação desses espaços de representação com as entradas e os espaços abertos (Corrales Álvarez, 2014, pp. 1349-1353).

Por sua vez, Complutum, um municipium romano implantado na zona de confluência dos rios Henares e Camarmilla, cuja fundação terá ocorrido na época de Augusto, conheceu o primeiro projeto de urbanização ao longo do período júlio-cláudio. Os dados disponíveis sobre o plano fundacional complutense permitem evidenciar a estruturação de uma malha urbana ortogonal que conformava quarteirões regulares, sendo aqueles incluídos nas regiones I e IV, os mais próximos à confluência dos rios, com formato retangular, enquanto os demais apresentam forma quadrada, com 1 actus de lado (120 pedes) (Rascón Marqués \& Sánchez Montes, 2014, pp. 309-312).

Os quarteirões das regiones das partes nascente e poente da cidade apresentam ligeiras diferenças formais e dimensionais, no entanto, é possível reconhecer um projeto urbanístico que previa a construção de pórticos ao longo das vias, os quais estariam associados com a proteção contra as intempéries climatéricas do centro peninsular (Rascón Marqués \& Sánchez Montes, 2017, p. 129), mas que também serviu para dar uma unidade paisagística à cidade.

Atualmente, são reconhecidas oito casas em Complutum, as quais documentam uma grande variedade dimensional, ocupando um, dois ou quatro lotes, os quais são definidos por quartos dos quarteirões. A variedade tipológica das casas é igualmente significativa, existindo domus de átrio, de peristilo e de pátio.

O local onde foram construídas as habitações parece ter tido grande influência na disposição do elemento distribuidor, como se verifica nas chamadas "Casa de los Grifos" e na "Casa de Baco", que ocupavam a totalidade dos quarteirões em que se implantaram. Trata-se de domus de peristilo centrado, cujos espaços adjacentes aos pórticos foram utilizados para a instalação de tabernae, ou para instalar grandes salas de representação, aproveitando-se assim os eixos das colunatas dos jardins e as perspetivas de simetria e axialidade que eles criavam (Sánchez Montes, 2011, pp. 174-176). Por outro lado, ao analisarmos a "Casa del Átrio" e a "Casa de la Lucerna de la Máscara Trágica”, verificamos que os espaços organizadores das habitações não são centrados, mas sim traseiros, facto a que não será alheia a circuns- 
tância dessas casas ocuparem, respetivamente, um quarto e meio de quarteirão, o que reduziu significativamente a área disponível para implantar os seus compartimentos, pelo que foi necessário recuar o espaço aberto e sacrificar parte de seu ambulacrum, mas mantendo a sua função ordenadora (Sánchez Montes, 2011, p. 178).

Quando analisamos as cidades do NO da Hispania, observamos processos idênticos aos registados no urbanismo e arquitetura de Augusta Emerita e Complutum nas cidades de Lucus Augusti, Asturica Augusta e de Bracara Augusta.

Bracara Augusta foi fundada entre 16/15 a.C., tendo conhecido a primeira fase de urbanização entre Augusto e o período júlio-cláudio. No entanto, as primeiras casas de elite parecem ter sido construídas a partir de meados do século I, intensificando-se a sua construção na época flávia. Trata-se de uma cidade cujo plano fundacional estabelecia uma malha ortogonal, na qual os eixos viários principais apresentam uma largura de 24 pedes $(7.24 \mathrm{~m})$, enquanto os demais apresentam metade desse valor. Os quarteirões, exclusivamente quadrados, possuem cerca de 144 pés $(42.76 \mathrm{~m})$ de lado e apresentam-se envolvidos por pórticos com cerca de 12 pedes (3.12m) de profundidade, o que conformava um espaço construível no interior dos quarteirões de cerca de 1 actus quadrado (120x120 pedes ou $35.52 \times 35.52 \mathrm{~m}$ ) (Martins \& alii, 2017a).

Em Bracara Augusta, o parcelamento dos quarteirões parece ter dado origem a lotes retangulares que ocupavam meio quarteirão, que corresponde ao valor mais pequeno que podemos atribuir às unidades domésticas conhecidas, pois não foi possível reconhecer lotes de menores dimensões, o que não significa que não possam ter existido, à semelhança do que acontece em Complutum. Assim, podemos concluir da diversidade formal e dimensional das domus de Bracara Augusta, que ou ocupavam a totalidade dos quarteirões, como aconteceu com as domus das Carvalheiras, do ex Albergue Distrital e das Cavalariças, ou meio quarteirão, conforme se encontra demonstrado nas zonas arqueológicas da Escola Velha da Sé/rua Frei Caetano Brandão nos 166-168 e da rua Afonso Henriques nos 42-56 (Magalhães, 2019).

Na cidade de Bracara Augusta é possível perceber uma relação harmoniosa entre as entradas e o ritmo dos pórticos que rodeavam os quarteirões, verificando-se uma axialidade associada aos espaços internos das casas, formalizada pelo alinhamento do uestibulum com os espaços abertos das casas, sejam átrios ou peristilos, mas também com salas de receção/ representação, por vezes implantadas no sentido oposto ao das entradas, situação que surge bem documentada na domus do ex-Albergue Distrital, cuja entrada foi alvo de monumentalização através da implantação de duas colunas que definem um pequeno pórtico, exterior à porta, de modo a que visualmente o ritmo de colunatas do quarteirão era reproduzido na entrada e no peristilo (Magalhães, 2019).

\section{ALGUMAS CONSIDERAÇÕES SOBRE A APLICAÇÃO DOS MODELOS ITÁLICOS NAS CASAS ROMANAS DA HISPÂNIA}

Os exemplares de arquitetura doméstica encontrados por toda a Hispania documentam uma forte influência da gramática arquitetónica produzida e desenvolvida na Itália e uma grande diversidade de usos desse léxico, aplicado em diferentes soluções compositivas. De facto, mais do que reproduzidos ou imitados, os modelos itálicos foram constantemente emulados e reinterpretados, de acordo com as especificidades, quer materiais e topográficas das cidades, quer relativas ao nível social e económico dos seus proprietários.

Uma vez que os proprietários das habitações participavam na elaboração dos projetos arquitetónicos e decorativos que deram origem às grandes domus implantadas nas cidades do Império, podemos associar a incorporação de elementos que compunham o cenário urbano no interior das habitações, como a projeção do externo/público ao interno/privado, através da qual os proprietários procuravam projetar as suas posições de controlo da vida cívica das cidades, a sua riqueza, oriunda da terra, mas também do comércio, e o seu estatuto, o qual resultaria dos cargos que ocupavam na administração local, conventual ou provincial. Na verdade, o continuum causado pela centralidade das entradas das habitações em relação ao intercolúnio das colunatas dos pórticos induzem a participação dos proprietários nas atividades públicas da cidade, sendo o prolongamento do exterior para o interior (e vice-versa) reiterado pelos uestibula alinhados com os peristilos ou átrios porticados, espaços que também recorriam às colunatas e, desta forma, também reproduziam o ritmo das paisagens urbanas (Wallace-Hadrill, 2015).

De facto, a necessidade de projeção pública das 
elites das cidades romanas, sobretudo em épocas fundamentais para a manutenção do poder dessas personagens, como nos períodos eleitorais, criavam fortes motivações para o investimento em espaços e soluções arquitetónicas sempre mais elaboradas e sumptuosas, tendo em vista impressionar e convencer os habitantes das cidades, sobretudo aqueles que possuíam cidadania latina ou romana e, portanto, direito ao voto.

A leitura atenta ao tratado De Architectura de Vitrúvio permite assinalar o variado léxico arquitetónico à disposição dos proprietários para conseguir o efeito desejado, o qual passava por uestibula regalia alta, atria et peristylia amplissima, siluae ambulationesque laxiores ad decorem maiestatis perfectae, tornando-se assim o interior da habitação acessível à altura de alguém qui honores magistratusque gerundo praestare debent officia ciuibus (VI.V.2). A obra assinala também a relação com o espaço externo que encontramos nas cidades com pórtico da Hispania romana (Vitr. De arch. VI.V.3). Esse recurso permitia reforçar o conceito de rus in urbe, próprio dos uiridaria dos peristilos, sem perder o caráter de natura capta. Com efeito, ao contemplar o jardim a partir dos ambulacra do peristilo tinha-se certamente a perceção de um espaço selvagem, mas controlado, sensação bem assinalada pelos elementos decorativos espalhados por esses espaços, como fontes e tanques, mas também pelas colunatas que os encerravam, que evocavam, um sentido bem próximo daquele que regia a delimitação dos pomoeria das cidades, momento em que o espaço urbano, ordenado, se separava do caótico ager (Wallace-Hadrill, 2015).

Depreende-se da leitura proposta que a casa romana não pode ser entendida como o resultado, nem da repetição de um modelo repetitivo e único de um esquema de organização da casa, com base num sistema axial de organização dos compartimentos, presente na casa pompeiana, nem da aplicação de um tipologia rígida, que definia os critérios de uma casa de átrio, de uma casa de peristilo, ou uma casa de átrio e peristilo. Será mais correto entender a casa romana como uma linguagem, necessariamente variável em termos morfológicos, mas também como um léxico, composto por unidades gramaticais que exprimem várias possibilidades semânticas, harmoniosamente resolvidas na solução arquitetónica que configura a sintaxe da habitação, a qual é necessariamente fruto de diversos fatores, mas sobretu- do um claro reflexo das atividades do proprietário e da sua família e das necessidades decorrentes de exibição pública do seu estatuto no quadro do corpo cívico das cidades. Na verdade, a casa romana era o espelho da classe e riqueza dos seus ocupantes, refletindo nas suas características arquitetónicas o seu estatuto social, pelo que a casa funcionava como uma poderosa linguagem que, numa sociedade pouco letrada, transmitia lógicas de poder, hierarquias e valores. Desta forma, as domus eram o cenário principal da vida política e social dos seus proprietários, estabelecendo a exibição física do seu poder económico, operando como estrutura de representação e controlo social.

\section{FONTES IMPRESSAS}

VITRUVIUS. On Architecture VI-X. Frank Granger (trad.) (1934) - Loeb Classical Library 280, Harvard University Press.

\section{BIBLIOGRAFIA}

BELTRÁN LLORIS, Miguel (1976) - Arqueología e Historia de las Ciudades Antiguas del Cabezo de Alcalá de Azaila. Zaragoza: Teruel.

BELTRÁN LLORIS, Miguel (1991) - La colonia Celsa. In La casa urbana hispanorromana: ponencias y comunicaciones. Zaragoza: Institución Fernando El Católico, Zaragoza, pp. 131-164.

CORRALES ÁlVAREZ, Álvaro (2014) - La arquitectura doméstica de Augusta Emerita. Cáceres: Universidade da Extremadura (Tese de Doutoramento).

CRUZ, Gonçalo (2015) - O surgimento do espaço urbano no Noroeste da Ibéria. Um reflexão sobre os oppida pré-romanos. In MARTÍNEZ PEÑIN, Raquel; CAVERO DOMÍNGUEZ, Gregória (Eds) - Evolución de los espacios urbanos y sus territorios en el Noroeste de la Península Ibérica. León/ Braga: Instituto de Estudios Medievales da la Unviversidad de León e Unidade de Arqueologia da Universidade do Minho, pp. 403-424.

CRUZ, Gonçalo (2018) - Northern Portugal in the transition of Era: from the hillforts, through the oppida, till the roman integration, In FONTES, Luís; CRUZ, Gonçalo; ALVES, Mafalda (eds.) - Actas do Simpósio Internacional: Interações Culturais e Paisagens em Mudança na Europa (séc. $2^{\circ}$ a.C. / séc. $2^{\circ}$ d.C.). Braga: Unidade de Arqueologia da Universidade do Minho, pp. 73-89.

ECKSTEIN, Arthur (2006) - Mediterranean anarchy, interstate war, and the rise of Rome. Los Angeles/London: University of California Press.

GONZÁLEZ RUIBAL, Alfredo (2004) - Material Culture and artistic expression in Celtic Gallaecia. In ARNOLD, 
Bettina; ALBERRO, Manuel (eds.) - The Celts in the Iberian Peninsula. Milwaukee: University of Wisconsin (E-Keltoi; 6), pp. 113-67.

GONZÁLEZ RUIBAL, Alfredo (2006/2007) - Galaicos. Poder y comunidade $n$ el Noroeste de la Península Ibérica (120o a.C. - 50 d.C.). A Coruña: Museo Arqueolóxico e Histórico da Coruña (Brigantium; 18).

FARIA, António (1998) - Algumas questões em torno da fundação de Augusta Emerita. Revista Portuguesa de Arquelogia. 1:1, pp. 161-167.

GROS, Pierre (2006) - L’Architecture romaine. Du début du IIIe siècle av. J.-C.à la fin du Haut Empire: Maisons, palais, villas et tombeaux. Paris: Editions A\&J Picard (v. 2).

HERCE SAN MIGUEL, Ana; PUNTER GÓMEZ, María; VICENTE REDÓN, Jaime; ESCRICHE JAIME, Carmen; MARTÍN RODRIGO, Jesús (1989) - Un pavimento de Opus Signinum com epígrafe ibérico. In Mosaicos romanos: Actas de la I Mesa Redonda Hispano-Francesa sobre Mosaicos Romanos (Madrid, 1985). Madrid, pp. 11-42.

HERCE SAN MIGUEL, Ana; PUNTER GÓMEZ, María; VICENTE REDÓN, Jaime; ESCRICHE JAIME, Carmen (1991) - La Caridad (Caminreal, Teruel). In La casa urbana hispanorromana: ponencias y comunicaciones: Congreso sobre la Casa- Urbana Hispanorromana (Zaragoza, Espanha, 1988). Zaragoza; Institución Fernando el Católico, pp. 8-13o.

LEMOS, Francisco (2009) - A cultura castreja no Minho. Espaço nuclear dos grandes povoados proto-históricos do Noroeste peninsular. In Pereira, Paulo (coord) - Minho. Traços de Identidade. Braga: Conselho Cultural da Universidade do Minho, pp. 122-213.

MAGALHÃES, Fernanda (2019) - A domus Romana no Noroeste Peninsular: Construção, Arquitetura e Sociabilidades. Braga: Universidade do Minho (Tese de Doutoramento).

MAR, Ricardo; RUIZ DE ARBULO, Joaquín (1993) - Ampurias romana. História, arquitectura y arqueología. Sabadell: Ed. Ausa.

MARTINS, Manuela (1985) - Sondagens Arqueológicas no Castro do Monte do Padrão, em Santo Tirso. Cadernos de Arqueologia. Série II. 2, pp. 217-230.

MARTINS, Manuela (1990) - O povoamento proto-histórico e a romanização da bacia do curso médio do Cávado. Cadernos de Arqueologia. Braga (Monografias; 5).

MARTINS, Manuela; MAGALHÃES, Fernanda; MARTÍNEZ PEÑÍN, Raquel; RIBEIRO, Jorge (2016) - The housing evolution of braga between Late Antiquity and the Early Middle Ages. Arqueologia Medieval. Lérida. VIII, pp. 35-52.

MARTINS, Manuela; RIBEIRO, Maria; RIBEIRO, Jorge; MAR, Ricardo (2017a) - Topografia e urbanismo fundacional de Bracara Augusta. In DOPICO CAÍNZOS, María; VILLANUEVA ACUÑA, Manuel, eds. - In Roma nata, per Italiam fusa, in provincias manat. A cidade romana no noroeste: no- vas perspectivas. Lugo: Servizo de Publicacións da Deputación de Lugo (Philtáte. Studia et acta antiquae Callaeciae; Vol. 2), pp. 203-226.

MATEOS CRUZ, Pedro (1994-95) - Reflexiones sobre la trama urbana de Augusta Emerita. Anas. Mérida. 7-8, pp. $233-247$.

MATEOS CRUZ, Pedro (2011) - Topografía y urbanismo de Augusta Emerita. In Actas Congreso Internacional 19102010: El Yacimiento Emeritense. Mérida: Consorcio Ciudad Monumental Histórico-Artística y Arqueológica de Mérida, pp. 127-144.

MOREIRA, Álvaro (2005) - Estação arqueológica do Monte do Padrão: o Castro do Monte do Padrão: Do Bronze Final ao fim da Idade Média. Santo Tirso: Câmara Municipal de Santo Tirso.

MOREIRA, Álvaro (2009) - "Castellum Madiae" formação e desenvolvimento de um "aglomerado urbano secundário" no ordenamento do povoamento romano entre Leça e Ave. Santiago de Compostela: Universidade de Santiago de Compostela (Tese de Doutoramento).

PESANDO, Fabrizio (1997) - Domus. Edilizia privata e società pompeiana fra III e I secolo a.C.. Roma.

RASCÓN MARQUÉS, Sebástian; SÁNCHEZ MONTES, Ana (2014) - "Complutum” de la ciudad clásica a la deconstruida a través de 700 años de historia. In VAQUERIZO GIL, Desiderio; Garriguet Mata, José; León Muñoz, Alberto (coord.) - Ciudad y territorio: transformaciones materiales e ideológicas entre la época clásica y el Altomedioevo. Córdoba: Universidad de Córdoba, Servicio de Publicaciones (Monografias de arqueología cordobesa; 20), pp. 309-324.

RASCÓN MARQUÉS, Sebástian; SÁNCHEZ MONTES, Ana (2017) - La ciudad romana de Complutum nuevos datos, nuevas interpretaciones. Vides monumenta veterum: Madrid y su entorno en época romana. Comunidad de Madrid: Museo Arqueológico Regional, Alcalá de Henares (Zona arqueológica; №. 20; 1,), pp. 127-143.

SÁNCHEZ BARRERO, Pedro (2007) - Nuevos datos sobre el trazado viario urbano de Augusta Emerita en el cerro del Calvario. Memoria. 10, pp. 113-119.

SÁNCHEZ MONTES, Ana (2011) - Aportaciones al conocimiento de la casa privada romana en España: La domus en la ciudad de Complutum. In Actas de las octavas jornadas de Patrimonio Arqueológico en la Comunidad de Madrid. Madrid: Consejería de Cultura y Deportes. Dirección General de Patrimonio Histórico, pp. 171-182.

SILVA, Armando (1986) - A Cultura Castreja no Noroeste de Portugal. Paços de Ferreira: Museu Arqueológico da Citânia de Sanfins.

SILVA, Armando; MACHADO, José (2007) - Banhos Castrejos do Norte de Portugal. In Pedra Formosa - Arqueologia Experimental. Vila Nova de Famalicão: Câmara Municipal de 
Vila Nova de Famalicão/Museu Nacional de Arqueologia, pp. 20-6o.

WALLACE-HADRILL, Andrew (2015) - What makes a Roman House a "Roman House"? in TUORI, Kaius; NISSIN, Laura (eds.) - Public and Private in the Roman House and Society. Rhode Island, Portsmouth (Journal of Roman Archaeology Supplementary Series 102), pp. 177-186.
ZANKER, Paul (1988) - The Power of Images in the Age of Augustus. Ann Arbor: The University of Michigan Press.

ZANKER, Paul (1998) - Pompeii, Public and Private Life. London: Harvard University Press.

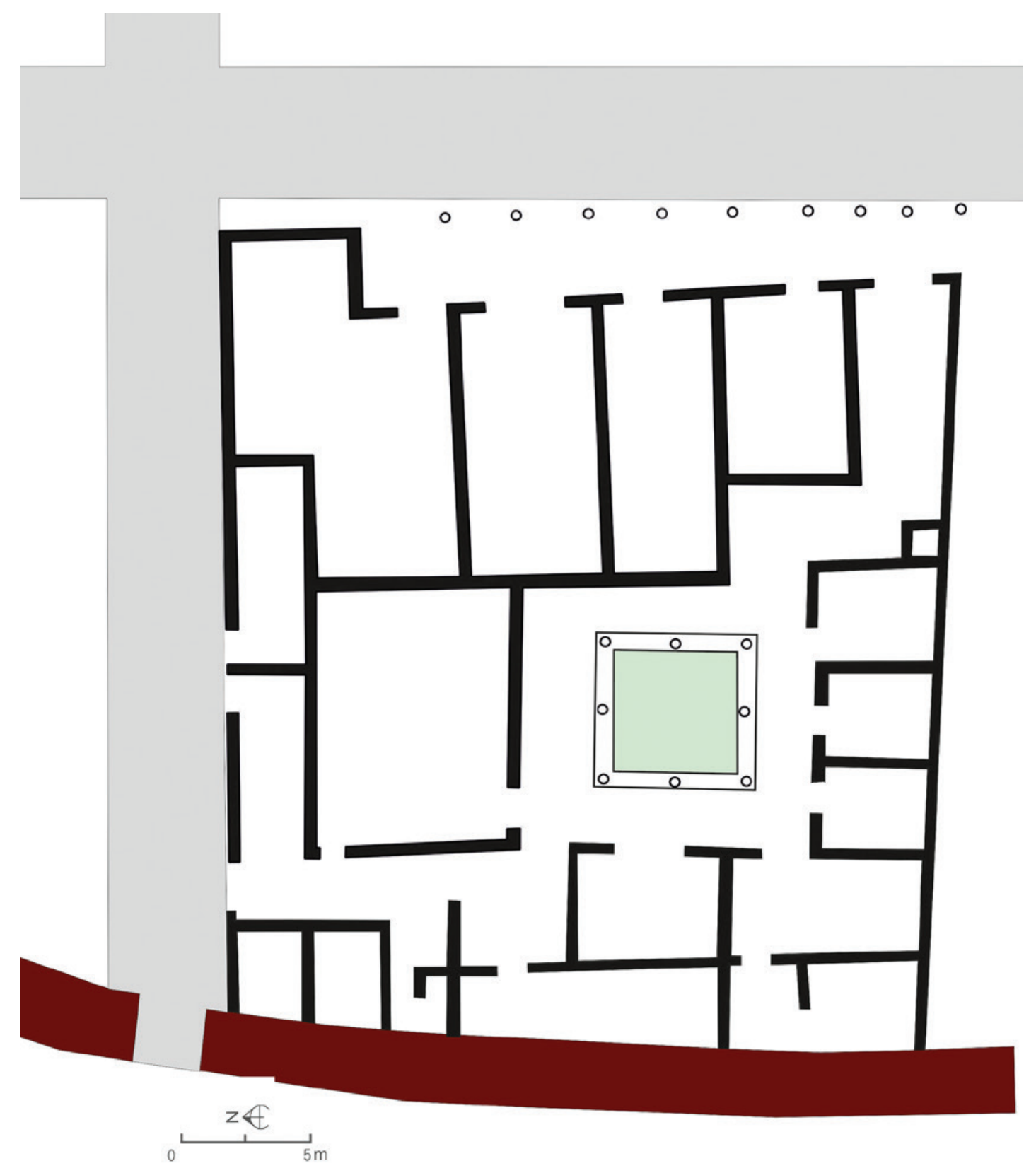

Figura 1 - Planta da 'Casa da 6’ Mouraria (Magalhães, 2019). 


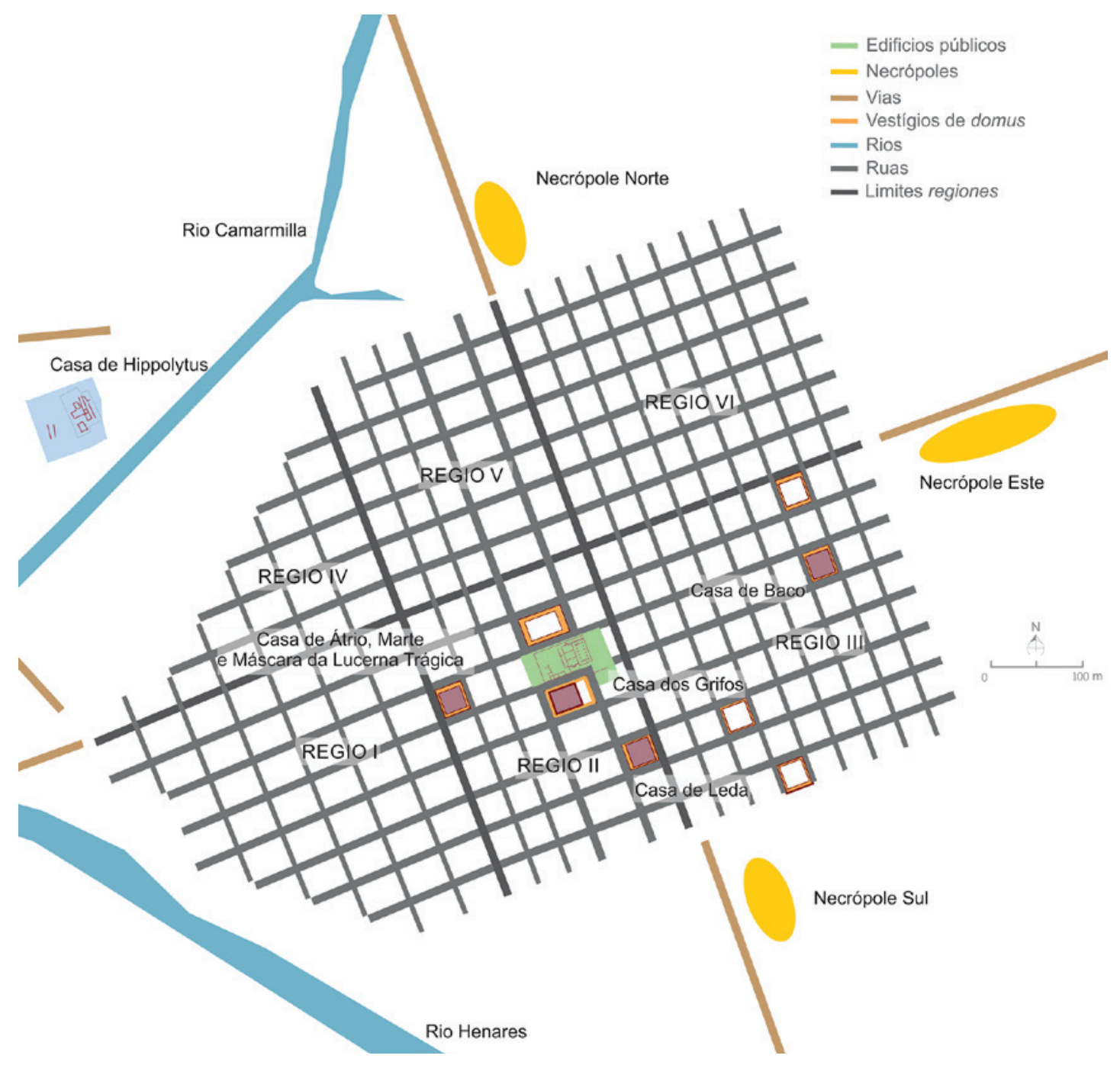

Figura 2 - Planta da cidade de Complutum com a identificação das domus (Magalhães, 2019).
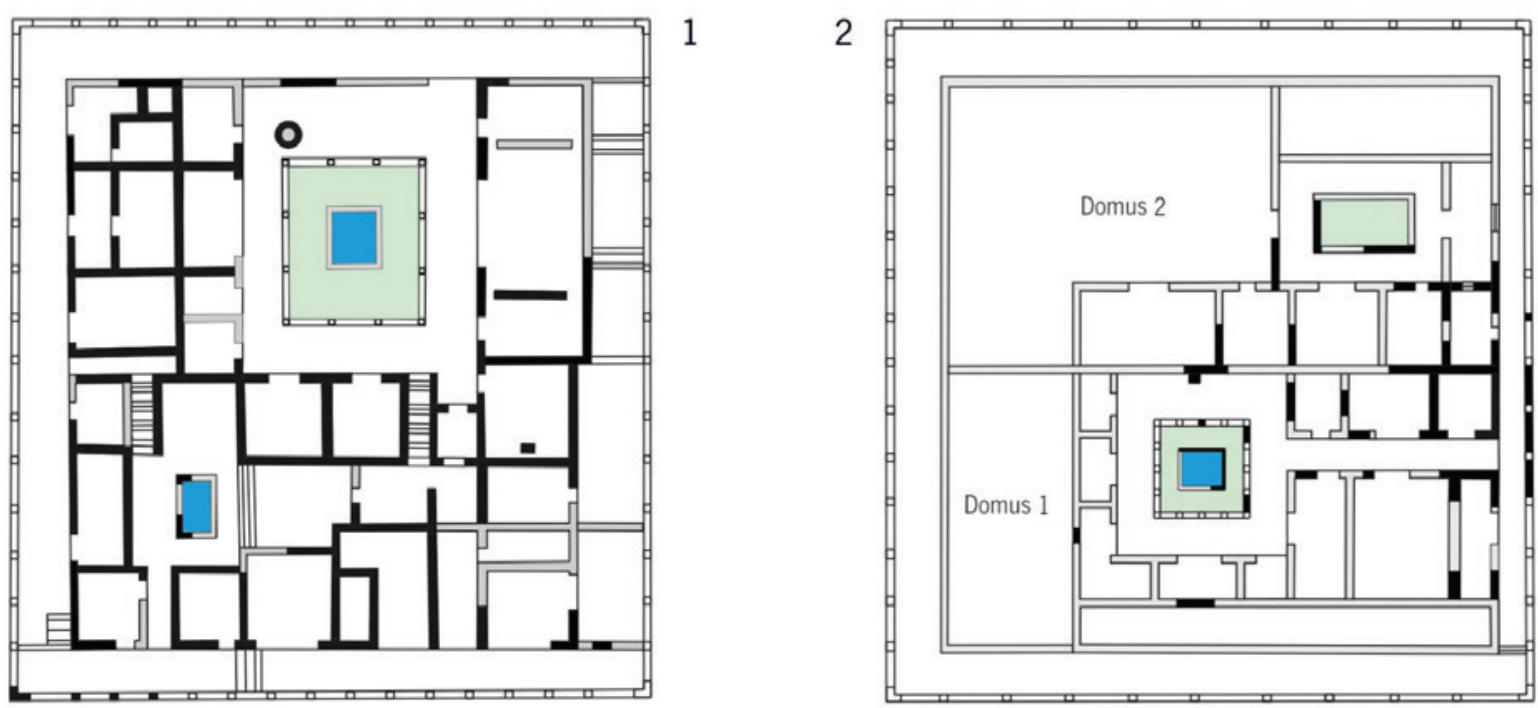

Figura 3 - Modelos das domus identificadas em Bracara Augusta.1. Domus das Carvalheiras; 2. Domus Escola Velha da Sé/rua Frei Caetano Brandão nºs 166-168. 


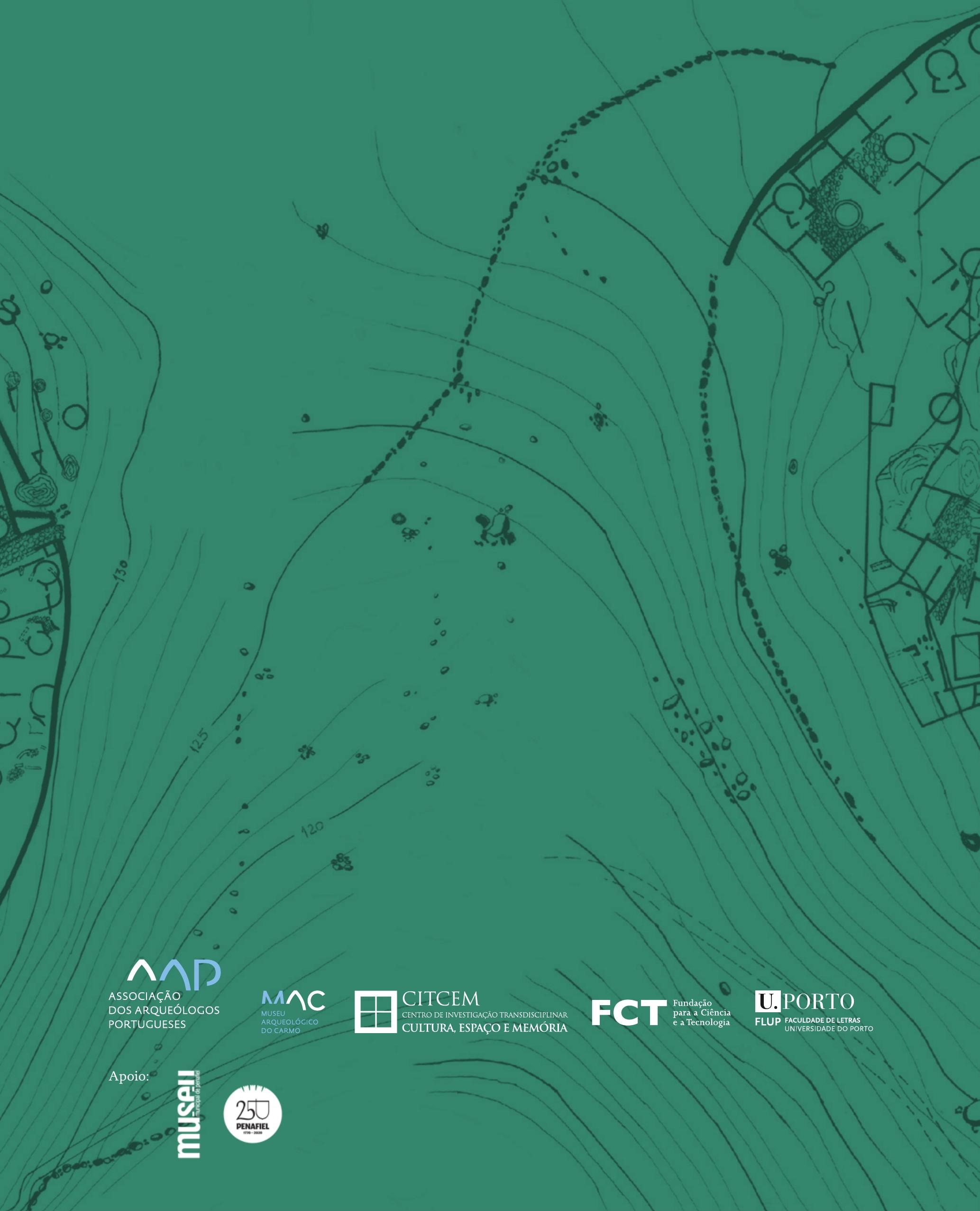

